\title{
Awareness about PCPNDT act among undergraduate students of a medical college in Puducherry
}

\author{
Lal Bahadur Palo*, Neelima Singh Chauhan, T. Parvathi, Ramesh Chand Chauhan
}

Department of Obstetrics \& Gynaecology, Pondicherry Institute of Medical Sciences, Puducherry, India

Received: 19 August 2015

Accepted: 3 September 2015

\section{*Correspondence:}

Dr. Lal Bahadur Palo,

E-mail: palolalbahadur@gmail.com

Copyright: (C) the author(s), publisher and licensee Medip Academy. This is an open-access article distributed under the terms of the Creative Commons Attribution Non-Commercial License, which permits unrestricted non-commercial use, distribution, and reproduction in any medium, provided the original work is properly cited.

\begin{abstract}
Background: Sex selective abortions have become a significant social phenomenon in contemporary India. In order to curb sex selective abortions, the Pre-Natal Diagnostic Techniques (PNDT) Act was passed in the year 1994.

Methods: A cross-sectional study was conducted by the Department of Obstetrics and Gynecology in Puducherry among 75 medical under-graduate students. A semi-structured, pre-designed questionnaire was used to collect the information on their knowledge, attitude and perception regarding gender discrimination and prenatal sex determination act.

Results: Only $34(45.3 \%)$ students were correctly aware of the prevailing sex ratio in India. Most common source of information for awareness was internet $(44.1 \%)$, followed by newspaper $(41.1 \%)$, and family/friends $(14.7 \%)$. Majority $(74.7 \%)$ of the students were aware of the PCPNDT Act. Awareness about PCPNDT Act among female students $(85.4 \%)$ was higher as compared to male students $(61.8 \%)$. Only half of the students $(56.0 \%)$ correctly reported about the punishment for sex determination and implication of feticide (fine and imprisonment both).

Conclusions: Awareness regarding the altered sex ratio and the PCPNDT Act was poor among medical undergraduates. In order to combat the poor awareness regular workshops and continuing medical education sessions (CMEs) should be conducted.
\end{abstract}

Keywords: Sex ratio in India, Sex selective abortions, PCPNDT Act

\section{INTRODUCTION}

Sex selective abortions have become a significant social phenomenon in contemporary India. Although the practice of female infanticide has been prevalent since time immemorial, in recent years sex-selection technologies such as amniocentesis and ultrasound have allowed parents to abort female fetus. ${ }^{1,2}$ In addition to the various methods undertaken to eliminate baby girls, sexselective abortion has also contributed significantly to alarming sex ratio. Sex selective abortions are most prevalent in patriarchal societies such as those in India and China.
Female feticide cuts across all social and economic boundaries. Even the educated, urban and wealthy people too often nurture a desire for a male child, and although they may not kill their daughter after she is born, they find out the sex of their child, and abort female fetuses. ${ }^{3}$ Due to portability of technology, sex selective abortions have reached even the remote places of India contributing to increase in female feticide. ${ }^{4}$ Female infanticide was made illegal for the first time by the British in India, with the passing of the Female Infanticide Prevention Act, $1870 .^{5}$ The recent census data for India reveals that in the age group of 0-6 years, the sex ratio is 914 girls to 1000 
boys. ${ }^{6}$ This is the lowest sex ratio recorded since India's Independence in 1947.

In order to curb sex selective abortions in India, the PreNatal Diagnostic Techniques (Regulation and Prevention of Misuse) Act was passed in the year 1994. ${ }^{7}$ The Act prohibited determination of sex of the fetus and stated punishment for the violation of the provisions. Since then, various amendments have been made and the act was changed to Pre-Conception and Pre-Natal Diagnostic Techniques (PCPNDT) Act in the year 2003. ${ }^{8}$

When couples intend to go for sex selection, the first person they approach are the people in the medical field. Although disclosing the sex of a fetus is illegal, there are medical practitioners who disclose it for an enhanced fee, and then give an option of sex selective abortion. Misuse of advanced technology by doctors is of great concern contributing towards female feticide. It is of utmost importance to sensitize undergraduate medical students so that, as a future health care provider, they will not indulge in such unethical practice and can actually help in changing the mindset of parents.

The Medical Council of India has also laid stress on the fact to educate doctors about humanities from the beginning of their medical carrier. In order to sensitize and educate young medical undergraduate students towards social and ethical issues, the Pondicherry University recently introduced a new curriculum for Community Medicine including Humanities as a part of undergraduate teaching. ${ }^{9}$ The present study was conducted among medical undergraduates to assess their awareness regarding pre-conception pre-natal diagnostic techniques act.

\section{METHODS}

A cross-sectional study was conducted by the Department of Obstetrics and Gynaecology of Pondicherry Institute of Medical Sciences, in Puducherry, South India. All undergraduate students of $\mathrm{VII}^{\text {th }}$ semester MBBS participated in the study.

A Pre-designed questionnaire was used to collect information on their knowledge, attitude and perception regarding gender discrimination and prenatal sex determination act. Questions were developed by reviewing literature on the vital statistics data of India and current prevalent practices regarding methods of sex selection and related legal laws. Both open-ended and closed-ended questions related to the current sex ratio in India, Pre-Conception and Pre-Natal Diagnostic Techniques (PCPNDT) Act, female feticide, measures to combat it, and its punishment for misuse were asked. The purpose of the study was explained to the participants and informed verbal consent was taken. Information given by the participants and their identity were kept confidential. Data were entered in Microsoft Excel 2007 and were analysed by using Statistical Package of Social Sciences
(SPSS) software. Proportions were estimated and chi square test was applied. $\mathrm{P}$ value of $<0.05$ was taken as significant.

\section{RESULTS}

Among a total of 75 students, $41(54.7 \%)$ were female and $34(45.3 \%)$ were male. As shown in Table 1 , only 34 $(45.3 \%)$ students were aware of the prevailing sex ratio in India. The awareness was better among male (47.1\%) as compared to female students $(43.9 \%)$ but the difference was not statistically significant $(\mathrm{P}$ value $>0.05)$. Among the 34 students, who were aware of the present sex ratio in India, $44.1 \%$ reported internet as a source of information, followed by newspaper (41.1\%), and family/friends (14.7\%). Only $5.9 \%$ students reported television as the source of information regarding the decreased sex ratio (Table 2).

Table 1: Awareness among students regarding declining sex-ratio.

\begin{tabular}{|lllll|} 
Variable & $\begin{array}{l}\text { Female } \\
(\mathrm{n}=41)\end{array}$ & $\begin{array}{l}\text { Male } \\
(\mathrm{n}=34)\end{array}$ & $\begin{array}{l}\text { Total } \\
(\mathrm{n}=75)\end{array}$ & $\begin{array}{c}\text { P- } \\
\text { value }\end{array}$ \\
\cline { 1 - 4 } Aware & $\begin{array}{l}\mathrm{n}(\%) \\
(43.9 \%)\end{array}$ & $\begin{array}{l}\mathrm{n}(\%) \\
(47.1 \%)\end{array}$ & $\begin{array}{l}\mathrm{n}(\%) \\
(45.3 \%)\end{array}$ & \multirow{2}{*}{$>0.05$} \\
\hline $\begin{array}{l}\text { Not } \\
\text { aware }\end{array}$ & 23 & 18 & 41 \\
\hline
\end{tabular}

Table 2: Sources of awareness regarding declining sex-ratio $(n=34)^{*}$.

\begin{tabular}{|lll|}
\hline Sources of awareness & n & $\%$ \\
\hline Internet & 15 & 44.1 \\
\hline Newspaper & 14 & 41.1 \\
\hline Family/friends & 5 & 14.7 \\
\hline Teachers & 4 & 11.8 \\
\hline Television & 2 & 5.9 \\
\hline *More than one response Possible & & \\
\hline
\end{tabular}

Table 3 shows the awareness of the participants regarding the Pre-Conception and Pre-Natal Diagnostic Technique (PCPNDT) Act. Fifty six (74.7\%) students reported to be aware of it. The awareness was better among female $(85.4 \%)$ as compared to male students $(61.8 \%)$ and the difference was statistically significant $(\mathrm{p}$ value $<0.01)$

Majority of the participants $(73.3 \%)$ reported that prenatal sex determination is a punishable offence, while $26.7 \%$ participants had no idea about the punishment. More than half of the students $(56.0 \%)$ correctly reported about the punishment for sex determination and implication of feticide (fine and imprisonment both). The correct response was higher among female students $(61.0 \%)$ as compared to male students $(50.0 \%)$. Thirteen $(17.3 \%)$ students were partly correct (either fine or imprisonment); (Table 4). 
Table 3: Awareness regarding PCPNDT Act.

\begin{tabular}{|lllll|} 
Variable & $\begin{array}{l}\text { Female } \\
(\mathbf{n = 4 1 )}\end{array}$ & $\begin{array}{l}\text { Male } \\
(\mathrm{n}=34)\end{array}$ & $\begin{array}{l}\text { Total } \\
(\mathrm{n}=75)\end{array}$ & $\begin{array}{l}\text { P- } \\
\text { value }\end{array}$ \\
\cline { 2 - 4 } Aware & $\begin{array}{l}\mathrm{n}(\%) \\
(85.4 \%)\end{array}$ & $\begin{array}{l}\mathrm{n}(\%) \\
(61.8 \%)\end{array}$ & $\begin{array}{l}\mathrm{n}(\%) \\
(74.7 \%)\end{array}$ & $<0.01$ \\
\hline $\begin{array}{l}\text { Not } \\
\text { aware }\end{array}$ & 6 & 13 & 19 & \\
\hline
\end{tabular}

Table 4: Awareness about type of punishment under the PCPNDT act.

\begin{tabular}{|lllll|}
\hline Response & $\begin{array}{l}\text { Female } \\
(\mathrm{n}=41)\end{array}$ & $\begin{array}{l}\text { Male } \\
(\mathrm{n}=34)\end{array}$ & $\begin{array}{l}\text { Total } \\
(\mathrm{n}=75)\end{array}$ & $\begin{array}{l}\mathrm{P} \text { - } \\
\text { value }\end{array}$ \\
\hline Correct & $\begin{array}{l}\mathrm{n}(\%) \\
(61.0 \%)\end{array}$ & $\begin{array}{l}17(\%) \\
(50.0 \%)\end{array}$ & $\begin{array}{l}\mathrm{n}(\%) \\
(56.0 \%)\end{array}$ & $>0.05$ \\
\hline $\begin{array}{l}\text { Partly } \\
\text { correct }\end{array}$ & $9(22.0 \%)$ & $\begin{array}{l}4 \\
(11.8 \%)\end{array}$ & $\begin{array}{l}13 \\
(17.3 \%)\end{array}$ & \\
\hline $\begin{array}{l}\text { Don't } \\
\text { know }\end{array}$ & $7(17.1 \%)$ & $\begin{array}{l}13 \\
(38.2 \%)\end{array}$ & $\begin{array}{l}20 \\
(26.7 \%)\end{array}$ \\
\hline
\end{tabular}

Table 5: Suggestions to improve the adverse sex-ratio in India $(\mathbf{n}=75) *$.

\begin{tabular}{|lll|}
\hline Response & n & $\%$ \\
\hline Strict implementation of the act & 66 & 88.0 \\
\hline More rigorous punishment & 66 & 88.0 \\
\hline Only creating awareness & 09 & 12.0 \\
\hline Creating awareness & 75 & 100.0 \\
\hline *More than one response Possible & & \\
\hline
\end{tabular}

All the $(100 \%)$ medical students were of the opinion that creating awareness among the medical fraternity and the community, about the declining sex-ratio, is an effective measure in reversing the skewed sex-ratio in India. As shown in Table 5, while $66(88.0 \%)$ students suggested that strict implementation of law and more rigorous punishment is necessary to deal with the declining sex ratio. But $9(12.0 \%)$ students suggested that creating awareness only, is more helpful.

\section{DISCUSSION}

The gender bias \& discrimination against girl child, which have been present for centuries, are now found to begin in the womb itself. The unborn girl child faces the peril of pre-birth elimination in the womb itself because of newer technologies. The present study was about awareness among medical students regarding adverse sex ratio and PCPNDT Act in India. Only 45.3\% students were aware about the declining sex ratio. The awareness was higher among males $(47.1 \%)$ than females $(43.9 \%)$ but the difference was not statistically significant. Our findings were consistent with other similar study done by
Avachat S et al in western Maharashtra, where among 79 interns, $41.9 \%$ of male and $25.7 \%$ of female interns were aware of female feticide and declining sex ratio. ${ }^{10}$ But, another study by Sindhu TK et al, among MBBS students of a medical college in Bhatinda, reported that $98.9 \%$ students had heard of female feticide. ${ }^{11}$ Similarly in a study conducted by Subitha et al, at a teaching institute in Mumbai, among hundred (III MBBS Part I) students, 98\% knew about prevailing sex ratio. Further, 56\% students came to know from mass media, $31 \%$ from health staff \& $13 \%$ from friends \& relatives. ${ }^{12}$ Whereas, in the present study $44.1 \%$ students came to know about the act from internet, $41.1 \%$ by newspaper and $14.7 \%$ by family/friends.

In our study, $74.7 \%$ students reported to be aware of the PCPNDT Act, while Sindhu T K et al reported that only $56.5 \%$ students had ever heard of PNDT Act. ${ }^{11}$

More than half $(73.3 \%)$ of the participants knew that prenatal sex determination and female feticide is a punishable offence. Of them, 56.0\% responded correctly about the punishment for sex determination and implication of feticide (fine and imprisonment both). Similarly, Subitha et al reported that maximum students knew that there is legal punishment for sex determination however, $86 \%$ were aware that the punishment includes fine \& imprisonment both. ${ }^{12}$ But, Sindhu TK et al reported that the correct knowledge regarding PCPNDT Act was poor among the medical undergraduates as only $63 \%$ knew that both fine and imprisonment are the penalties under this act. ${ }^{11}$

All the medical students in the present study suggested that creating awareness is an effective measure in reversing the skewed sex-ratio in India, while $88.0 \%$ students suggested that strict implementation of laws and more rigorous punishment is necessary to deal with the declining sex ratio. Similarly, in a study by Avachat $\mathrm{S}$ et al, majority of the interns $(77.2 \%)$ stated that creating awareness about declining sex ratio is an effective measure while $(62.2 \%)$ opined strict implementation of law is necessary to deal with this issue. ${ }^{10}$ Only $46.7 \%$ held the view that PCPNDT Act alone is not a sufficient tool for reducing female feticide by Sindhu TK et al. ${ }^{11}$

\section{CONCLUSION}

Awareness regarding the adverse sex ratio and the PCPNDT Act was poor among medical undergraduates. In order to combat the poor awareness and knowledge among medical undergraduates, conducting regular workshops and continuing medical education sessions (CMEs) should be conducted. ${ }^{14}$

The need of the hour is to sensitize future doctors about the ethics related to the inappropriate and indiscriminate use of technology. While the future doctors could join hands in efforts directed at improving the status of women in India, it is more urgent that they unite in 
curbing the threat posed by doctors and sensitizing them against such malpractices.

\section{Recommendations}

We strongly recommend that all medical universities to include such humanity classes to sensitize the medical students regarding the unethical practice \& thereby in turn create awareness in the community by health education during ROME (Reorientation of Medical Education) posting to eradicate this social menace. There is a need for strict law enforcement for violation of the PCPNDT Act.

\section{ACKNOWLEDGEMENT}

Authors would like to thank all the students who consented and participated in the study.

Funding: No funding sources

Conflict of interest: None declared

Ethical approval: Informed verbal consent of the study participants was taken.

\section{REFERENCES}

1. Vishwanath LS. Efforts of Colonial State to Suppress Female Infanticide: Use of Sacred Texts, Generation of Knowledge. Economic and Political Weekly. 1998;33(19):1104-1112.

2. C. Myers. Sex selective abortions in India. Global Tides. 2012;6(1):1-19.

3. Ratha CK, Mahapatra SK. India's Missing Daughters: An Ominous Sign for Democracy. Mediterranean Journal of Social Sciences. 2014;5(13):467-76.

4. Shinde AS, Lokhande T, Muluk AD. A Geographical Study of Spatial Variation in Rural-Urban Sex ratio in Solapur District of Maharashtra, International Interdisciplinary Research Journal. 2014;4(2):26268 .
5. Saravanan S. Female infanticide in India: a review of literature. Soc Change. 2002;32:58-66.

6. Ministry of Home Affairs, India. Census of India 2011. New Delhi: Office of the Registrar General \& Census Commissioner; 2011 Online. Available at:http://censusindia.gov.in/2011.

7. Annual report on implementation of the PreConception and Pre-Natal Diagnostic Techniques (Prohibition of Sex Selection) Act, 2005, PNDT Division Ministry of Health and Family Welfare Government of India ,New Delhi, April 10, 2015.

8. Sunderlal, Textbook of Community Medicine, CBS Publisher, Third edition.

9. www.pondi.edu.in/academic/syllabus/course and syllabus/medical courses/ MBBS, August 11, 2015.

10. Avachat S, Raut P, Zambare M, Gund D, Pundkar R. Perspectives of medical interns regarding female feticide and declining sex ratio in India. N Am J Med Sci. 2013;5(8):469-72.

11. Sidhu TK, Kumar S, Kaur PA. Study of knowledge and attitude of medical undergraduate students regarding prenatal sex determination and female feticide. Indian J Matern Child Health. 2011;13:2-6.

12. Patil S, Singh V, Chavan S, Gadkari M. Knowledge and attitude regarding PCPNDT act among medical undergraduates: a study conducted in teaching institute Mumbai. Innovative Journal of Medical and Health Science. 2014:4(2);83-85.

13. Singh AK, Singh K, Verma A. Study of medico-legal case management in tertiary care hospital. J Indian Acad Forensic Med. 2011;33:337-42.

14. Nath A, Sharma N, Knowledge and attitudes of medical students and interns with regard to female feticide, Indian Journal of Community Medicine. 2009;34:164.

Cite this article as: Palo LB, Chauhan NS, Parvathi $\mathrm{T}$, Chauhan RC. Awareness about PCPNDT act among undergraduate students of a medical college in Puducherry. Int J Reprod Contracept Obstet Gynecol 2015;4:1485-8. 